\title{
Pengabdian Kemitraan Masyarakat Pada Koperasi Simpan Pinjam
}

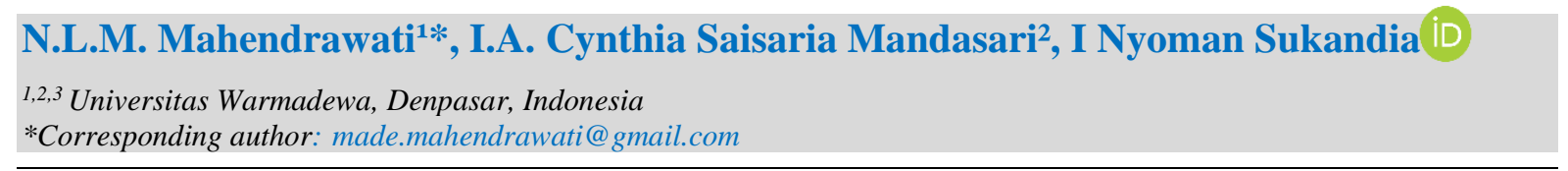

\begin{abstract}
Abstrak
Penerapan sistem manajemen koperasi yang belum tepat dimasa pandemi covid-19, model format perjanjian simpan pinjam yang belumsesuai dengan kondisi pandemi covid-19, kredit macet, menganalisa perjanjian kredit dan mengubahnya agar lebih baik serta mengawasi penarikan kredit macet. Beberapa hal tersebut merupakan masalah yang terdapat di koperasi simpan pinjam selama masa pandemi covid-19. Penelitian ini bertujuan untuk mengembangkan koperasi melalui pendekatan pembinaan, pendampingan, dan sosialisasi. Penelitian ini merupakan penelitian pengabdian yang berlokasi di Koperasi Simpan Pinjam Shanti Prapta Sedana. Karena kekuatan koperasi berada di tangan anggotanya, maka kesadaran akan disiplin dan fanatisme anggota sangat penting guna meningkatkan pemahaman koperasi serta etos koperasi yang perlu ditanamkan pada setiap anggota. Dalam rangka pengembangan sumberdaya manusia pada koperasi dapat menempuh pendekatan baik struktural maupun kultural. Pendampingan Koperasi Simpan Pinjam Santhi Prapta Sedana ini juga dilakukan via telefon, WhatsApp, Zoom Meeting, dan secara langsung agar lebih berjalan maksimal. Berdasarkan hasil penelitian pengabdian ini, tim pengabdian memberikan pendampingan dengan memberikan usulan-usulan terkait masalah penarikan kredit bermasalah dan membina para anggota yang bermasalah diantaranya reconditioning, restructuring, cashflow, write off.
\end{abstract}

Kata Kunci: Koperasi Simpan Pinjam, Sistem Manajemen

\section{Abstract}

Improper application of the cooperative management system during the covid-19 pandemic, the model of the savings and loan agreement format that is not by the conditions of the covid-19 pandemic, bad credit, analyzing credit agreements and changing them for the better and supervising the withdrawal of bad loans. Some of these are problems that exist in savings and loan cooperatives during the covid-19 pandemic. This study aims to develop cooperatives through coaching, mentoring, and socialization approaches. This research is service research located in the Shanti Prapta Sedana Savings and Loan Cooperative. Because the strength of cooperatives is in the hands of its members, awareness of the discipline and fanaticism of members is very important to increase understanding of cooperatives and the cooperative ethos that needs to be instilled in every member. In the context of developing human resources, cooperatives can take both structural and cultural approaches. The assistance of the Santhi Prapta Sedana Savings and Loans Cooperative is also carried out via telephone, WhatsApp, Zoom Meeting, and in-person so that it runs optimally. Based on the results of this service research, the service team assists by providing suggestions regarding the problem of withdrawing non-performing loans and fostering problematic members including reconditioning, restructuring, cashflow, write off.

Keywords: Savings and Loan Cooperative, Management System

\section{INTRODUCTION}

Provinsi Bali merupakan salah satu kompetisi terbaik untuk Koperasi di Indonesia. Hal ini dapat dilihat dari penghargaan yang telah diberikan oleh Kementrian Koperasi dan Usaha Kecil dan Menengah Republik Indonesia kepada koperasi-koperasi di Bali. Pemerintah pun optimis untuk terus mengembangkan koperasi dan UMKM di Bali secara baik dan benar agar kedepannya dapat memenuhi pasar baik dalam negeri maupun luar negeri. Keberadaan usaha dalam bentuk koperasi di Kabupaten Gianyar sebagai wilayah pengembangan pariwisata sangat diperlukan. Sehingga secara konstitusi setiap orang (pelaku Usaha) memiliki akses yang

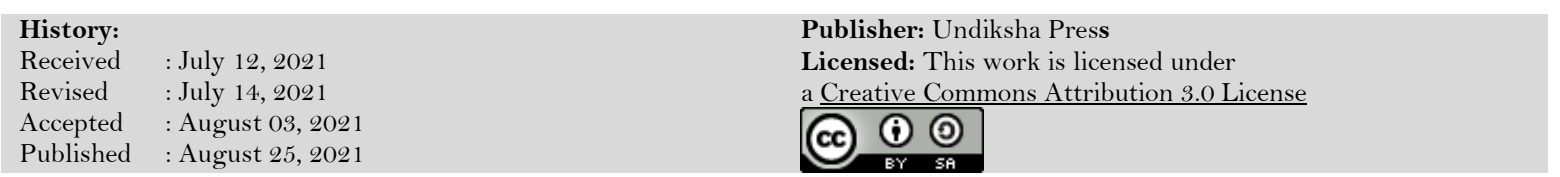


sama terhadap sumber daya ekonomi yang ada. Berdasarkan data Dinas Koperasi UKM di Kabupaten Gianyar, data per desember 2019 koperasi di Gianyar sebanyak 1239 koperasi yang tersebar di tujuh kecamatan kabupaten Gianyar dengan jumlah anggota 205.597 orang. Menyerap tenaga kerja sebanyak 10.698 orang sisa hasil usaha sebesar Rp. 67,44 milyar dengan total aset1, 42 trilliun. Sebanyak 286 koperasi dikatagorikan tidak aktif, 85,49 \% sudah melaksanakan rapat anggota tahunan (RAT). Kadis Koperasi dan UKM Kabupaten Gianyar Dewa Putu Mahayasa menargetkan pada tahun 2019 ini 90 persen koperasi melakukan RAT untuk tahun buku 2018. Koperasi Simpan Pinjam yang masih aktif pada tahun 2019 sejumlah 212 koperasi. Tingginya tingkat pertumbuhan koperasi di Kabupaten Gianyar dan menghadapi masa pandemi covid-19 saat ini ada beberapa permasalahan kredit bermunculan pula, salah satunya terjadi pada Koperasi Simpan Pinjam Santhi Prapta Sedana.

Terdapat beberapa permasalahan yang perlu dijadikan perbaikan. Pertama, penerapan sistem manajemen koperasi yang tepat dimasa pandemi covid-19; kedua, model format perjanjian simpan pinjam yang sesuai dengan kondisi pandemi covid-19; ketiga, memberikan pembinaan terhadap pengurus koperasi mengenai masalah kredit macet, menganalisa perjanjian kredit dan mengubahnya agar lebih baik serta mengawasi penarikan kredit macet. Oleh karena itu, pendampingan, sosialisasi dan pembinaan kepada anggota koperasi perlu untuk dilakukan (Citra Savitri \& Mumun Maemunah, 2021; Mariani et al., 2021; Wardana \& Wulaningrum, 2020). Adapun materi yang perlu disampaikan yaitu mengenai manajemen administrasi koperasi, format ketentuan perjanjian kredit simpan pinjam dan penyelesaian kredit macet. Solusi-solusi tersebut diindikasi dalam sebuah konsep pembinaan yang terintegritas antara para mitra serta para tim pengabdian masyarakat. Adapun pembinaan ini sejalan dengan visi dan misi Lembaga Pengabdian Masyarakat Universitas Warmadewa.

Dengan demikian, diharapkan setelah adanya pengabdian masyarakat di Kabupaten Gianyar ini khususnya pada Koperasi Simpan Pinjam Shanti Prapta Sedana adalah adanya format perjanjian simpan pinjam pada koperasi, meningkatnya pemahaman pengurus koperasi dalam menyelesaikan kredit bermasalah. Dengan pemahaman yang meningkat ini, barulah diharapkan adanya progress yaitu para pengurus koperasi simpan pinjam dapat mencegah terjadinya kredit bermasalah melalui model perjanjian yang standar dan dapat menyelesaikan pula permasalahan kredit macet yang terjadi di koperasinya masing-masing (Purwantini et al., 2017; Sujono et al., 2019; Suryaningsi \& Arif, 2020).

Beberapa penelitian pengabdian yang sejalan dengan penelitian pengabdian ini seperti yang dilakukan oleh (Wardana \& Wulaningrum, 2020) yang menyatakan bahwa kegiatan program pengabdian kemitraan masyarakat ini dapat meningkatkan kesadaran anggota dan pengurus koperasi akan potensi atau prospek koperasi tingkat dusun ini dalam jangka panjang. Kemudian penelitian yang dilakukan oleh (Christanto et al., 2019) menyatakan bahwa hampir seluruh peserta pelatihan sepakat setelah mendapatkan pelatihan, kemampuan, dan keterampilan dalam menggunakan fitur-fitur pada sistem informasi manajemen koperasi meningkat. Tujuan penelitian ini mengembangkan koperasi melalui pendekatan pembinaan, pendampingan, dan sosialisasi.

\section{MATERIALS AND METHODS}

Pelaksanaan kegiatan pengabdian di Koperasi Simpan Pinjam Shanti Prapta Sedana lingkungan kelod kangin Kelurahan Beng Kecamatan Gianyar Kabupaten Gianyar ini dengan metode bimbingan teknis dan ceramah dan pendampingan kepada para pengurus koperasi. Setelah usainya pendampingan, bimbingan teknis dalam bentuk ceramah ini, Fakultas Hukum Universitas Warmadewa masih akan melakukan pendekatan, memberikan bantuan hukum serta pembinaan mengenai pencegahan kredit bermasalah pada Simpan Pinjam Shanti Prapta Sedana, lingkungan kelod kangin, Kelurahan Beng, Kecamatan Gianyar, Kabupaten Gianyar. 
Dengan demikian kegiatan pengabdian masyarakat ini terus berlanjut dengan ceramah , pendampingan, bimbingan teknis ini berakhir.

Kegiatan PKM ini dilakukan melalui beberapa tahapan pelaksanaan. Pertama, melakukan survei lapangan untuk menetapkan lokasi mitra Kemudian melakukan wawancara diskusi secara partisipatif dalam menyusun dan merencanakan tahapan kegiatan yang mengarah pada solusi terhadap permasalahan yang dihadapi mitra dan target luaran. Setelahnya, dilakukan ceramah mengenai koperasi dan penyelesaian kredit bermasalah serta memberikan pendampingan pada pengurus koperasi. Disamping itu juga akan diberikan bimbingan teknis mengenai model format perjanjian kredit koperasi Kemudian melalui pembinaan tersebut akan dihasilkan model format perjanjian simpan pinjam yang baru. Sehingga sistem tata kelola manajemen koperasi yang baru terwujud, serta kredit koperasi yang bermasalah dapat terselesaikan. Untuk mencapai keberlanjutan dari hasil pemberdayaan masyarakat, monitoring, evaluasi, pendampingan dan pelaporan akan dilakukan secara periodik.

\section{RESULTS AND DISCUSSION}

\section{Hasil}

\section{Dampak Pandemi Covid-19 Terhadap Perekonomian}

Mudahnya penularan COVID-19 menyebabkan upaya pencegahan perlu untuk dipercepat. Merespon hal ini, pemerintah kemudian menerapkan kebijakan physical distancing atau pembatasan fisik dengan menjaga jarak minimal 1,8 meter antar orang. Namun karena kurang efektifnya penerapan kebijakan physical distancing, jumlah kasus masih kian meningkat dari hari ke harinya. Oleh karena itu pemerintah kemudian menerapkan kebijakan PSBB atau Pembatasan Sosial Berskala Besar di beberapa kota di Indonesia dengan jumlah kasus tinggi, atau yang lebih kita kenal dengan zona merah. Adanya PSBB menyebabkan kegiatan industri jadi turut terhambat. Sebagian besar perkantoran dan industri dilarang untuk beroperasi dalam kurun waktu yang relatif lama. Hal ini tentunya berdampak pada kerugian ekonomi bagi beberapa pelaku usaha.

Pertumbuhan ekonomi Indonesia diperkirakan meningkat sebesar 5,3\% pada tahun 2020. Namun akibat terjadinya pandemi, pertumbuhan ekonomi hanya mencapai kurang dari $2 \%$ saja (Hadiwardoyo, 2020). Berdasarkan data dari IMF, pada tahun 2020 pertumbuhan GDP Indonesia menurun sebanyak 4,5\% jika dibandingkan dengan tahun 2019. Jika dilihat lebih rinci pertumbuhan GDP Indonesia pernah turun drastis pada masa krisis tahun 1998, kemudian kembali stabil dan hingga tahun 2020 pertumbuhan GDP Indonesia hanya berada pada angka $0.5 \%$ saja (Sumarni, 2020). Hal ini sangat jauh dari persentase yang telah diperkirakan sebelumnya. Seperti yang telah dijelaskan sebelumnya, bahwa data agregat nasional belum bisa digunakan pada perhitungan pada sektor bisnis dengan skala kecil. Padahal, tak hanya sektor bisnis dengan skala besar saja yang turut terdampak, sektor bisnis dengan skala kecil pun turut terdampak. Adapun beberapa sektor bisnis yang mengalami kerugian besar antara lain bisnis yang mengandalkan keramaian seperti bisnis pariwisata, event pertunjukan, pameran dan mall. Kemudian ada juga bisnis pendukungnya seperti transportasi massal, ticketing, hotel, dan perdagangan musiman/souvenir. Ada juga bisnis yang tidak bisa menerapkan physical distancing seperti salon dan ojek. Kemudian ada juga bisnis produk tersier yang bergantung pada tabungan masyarakat seperti property, kendaraan pribadi, perawatan tubuh, hobi, dan lain sebagainya.

Beberapa kerugian yang dialami oleh entitas usaha antara lain hilangnya pendapatan akibat penurunan penjualan yang berbanding terbalik dengan pengeluaran, kerusakan produk akibat disimpan terlalu lama, kerugian akibat modal usaha yang terkuras, timbulnya biaya pesangon apabila terpaksa melakukan PHK, bahkan buruknya usaha dapat mengalami 
kebangkrutan. Tak hanya pada beberapa sektor usaha, perekonomian individu juga turut terdampak. Menurut data dari Badan Pusat Statistik, bahwa jumlah angkatan kerja pada Februari 2020 sebanyak 137,91 juta orang, naik 1,73 juta orang dibanding Februari 2019. Berbeda dengan naiknya jumlah angkatan kerja, Tingkat Partisipasi Angkatan Kerja (TPAK) turun sebesar 0,15 persen poin. Dalam setahun terakhir, pengangguran bertambah 60 ribu orang, berbeda dengan TPT yang turun menjadi 4,99 persen pada Februari 2020. Dilihat dari tingkat pendidikan, TPT Sekolah Menengah Kejuruan (SMK) masih yang paling tinggi diantara tingkat pendidikan lain, yaitu sebesar 8,49 persen. Pemutusan hubungan kerja, berdampak kepada pengangguran, kesulitan mencari pekerjaan, masyarakat miskin meningkat. Prediksi peningkatan jumlah kemiskinan di Indonesia.

\section{Peran Koperasi dalam Menyokong Perekonomian di Masa Pandemi Covid-19}

Koperasi berasal dari kata co yang berarti bersama serta operation yang mengandung makna bekerja. Jadi, secara leksikologis koperasi bermakna sebagai suatu kumpulan kerja sama yang beranggotakan orang-orang maupun badan-badan dimana ia memberikan kebebasan untuk keluar dan masuk sebagai anggotanya beranggotakan orang-orang atau badan hukum koperasi dengan melandaskan kegiatannya berdasarkan dengan prinsip koperasi sekaligus sebagai gerakan ekonomi rakyat yang berdasarkan atas azas kekeluargaan. Menurut Pasal 4 Undang-Undang Nomor 25 Tahun 1992, koperasi memiliki berbagai peran antara lain Membangun dan mengembangkan potensi dan kemampuan ekonomi anggota pada khususnya dan masyarakat pada umumnya untuk meningkatkan kesejahteraan ekonomi dan sosialnya, Berperan secara aktif dalam upaya mempertinggi kualitas kehjdupan manusia dan masyarakat, Memperkokoh perekonomian rakyat sebagai dasar kekuatan dan ketahanan perekonomian nasional dengan koperasi sebagai soko gurunya, Berusaha untuk mewujudkan dan mengembangkan perekonomian nasional yang merupakan usaha bersama berdasarkan asas kekeluargaan dan demokrasi ekonomi.

Koperasi sendiri sebagai suatu badan usaha yang bekerja sama dengan masyarakat dalam meningkatkan taraf perekonomian menuju lebih baik. Koperasi dianggap mampu menyentuh langsung masyarakat bawah, terutama para pelaku usaha yang terkena dampak pandemi. Koperasi diharapkan mampu menjadi motor penggerak ekonomi masyarakat seperti UMKM dan pedagang kecil untuk bangkit dan terus bergerak maju. Pandemi Covid-19 ini sekaligus menjadi momentum bersama untuk meningkatkan kerja koperasi agar lebih efisien. Karenanya, pemberdayaan koperasi merupakan langkah strategis menumbuhkan pembangunan nasional. Keberhasilan pemberdayaan koperasi tentunya diukur dari besarnya nilai kesejahteraan yang dirasakan anggotanya.

\section{Dampak Ekonomi dan Sosial Kegiatan Pengabdian Kemitraan pada Masyarakat}

Kegiatan pengabdian kemitraan pada masyarakat diharapkan dapat membantu berbagai permasalahan pada masa pandemi Covid-19 di Koperasi Simpan Pinjam Shanti Prapta Sedana, lingkungan kelod kangin Kelurahan Beng, Kecamatan Gianyar, Kabupaten Gianyar Kegiatan pengabdian masyarakat ini membawa dampa baik dari segi ekonomi maupun sosial. Dengan adanya kegiatan ini dapat membangun dan mengembangkan potensi dan kemampuan ekonomi anggota koperasi pada khususnya dan masyarakat di kabupaten Gianyar pada umumnya untuk meningkatkan kesejahteraan ekonomi dan sosialnya. Masyarakat diberi wadah untuk Berperan serta secara aktif dalam upaya mempertinggi kualitas kehidupan manusia dan masyarakat di lingkungan kelod kangin, Kelurahan Beng, Kecamatan Gianyar, Kabupaten Gianyar. Perekonomian rakyat lingkungan Kelod Kangin, Kelurahan Beng, Kecamatan Gianyar, Kabupaten Gianyar diperkokoh melalui koperasi sebagai dasar kekuatan dan ketahanan perekonomian nasional dengan koperasi sebagai soko- gurunya. Terwujudnya 
Upaya dalam mengembangkan perekonomian nasional, yang merupakan usaha bersama berdasarkan atas asas kekeluargaan dan demokrasi ekonomi.

\section{Kontribusi Mitra Terhadap Pelaksanaan}

Peranan koperasi sebagai suatu lembaga yang bertugas dalam mensejahterakan serta memajukan perekonomian rakyat telah banyak ditunjukkan ini ditunjukkan dalam pelaksanaan Kegiatan pengabdian kemitraan pada masyarakat yang dengan berbagai permasalahan pada masa pandemi Covid-19 pada Koperasi Simpan Pinjam Shanti Prapta Sedana, lingkungan kelod kangin Kelurahan Beng Kecamatan Gianyar Kabupaten Gianyar, memberikan kontribusi yaitu Meningkatkan taraf hidup masyarakat di di lingkungan kelod kangin Kelurahan Beng Kecamatan Gianyar Kabupaten Gianyar, mengembangkan demokrasi ekonomi di indonesia, serta mewujudkan pendapatan masyarakat yang adil dan merata dengan cara menyatukan, membina, dan mengembangkan setiap potensi yang ada

\section{Kontribusi Regulasi melalui Pemberian Pembinaan dan Sosialisasi}

Pendampingan analisis format perjanjian kredit koperasi dan penyelesaian kredit macet pada Koperasi, serta kerjasama dengan Dinas Koprasi Dan Usaha Mikro Kecil dan Menengah, Tenaga Kerja dan Transmigrasi Kabupaten Gianyar sebagai Pengawas terkait permasalahan penyelesaian dan pengawasan kredit macet. Sehingga tidak ada lagi kredit bermasalah pada kopersai simpan pinjam di kabupaten Gianyar umumnya dan pada Koperasi Simpan Pinjam Santhi Prapta Sedana khususnya.

\section{Pembinaan Manajemen Administrasi Koperasi pada Koperasi Simpan Pinjam Shanti Prapta Sedana}

Dalam pelaksanaannya, Koperasi simpan pinjam Shanti Prapta Sedana, lingkungan kelod kangin Kelurahan Beng Kecamatan Gianyar Kabupaten Gianyar untuk menjadi koperasi yang sehat, masih memiliki beberapa kendala terkait administrasi manajeen koperasinya. Dalam situasi pandemic covid- 19, membawa dampak ketidak teraturan arus dana yang terjadi dalam koperasi. Pencatatan dana masuk seharusnya terdiri dari Penerimaan simpanan pokok dan simpanan wajib untuk KSP, dan modal disetor untuk USP, Penerimaan angsuran pinjaman, baik pokok maupun bunga. Penerimaan simpanan berupa tabungan atau simpanan berjangka anggota. Sedangkan arus dana keluar di KSP/USP terdiri dari pemberian pinjaman. Penarikan simpanan berupa tabungan atau simpanan berjangka anggota. Pembayaran biaya-biaya usaha dan organisasi. Pembayaran simpanan pokok dan simpanan wajib untuk anggota KSP yang keluar; Pengembalian pinjaman kepada pihak ketiga beserta bunganya. Selain pengelolaan arus dana, permasalahan lainnya yang harus dibenahi pada koperasi adalah permasalahan SDM. Seperti yang telah dijelaskan sebelumnya, permasalahan pada terletak pada kurang aktifnya ang Simpan Pinjam Shanti Prapta Sedana anggota koperasi serta pengurus koperasi. Dalam hal ini, maka tim pengabdian memberikan beberapa solusi dalam bentuk pembinaan SDM dengan memberikan materi perbaikan SDM untuk simpan pinjam Shanti Prapta Sedana .

Dalam rangka pengembangan sumberdaya manusia pada koperasi dapat menempuh pendekatan baik struktural maupun kultural. Pada koperasi Simpan Pinjam Shanti Prapta Sedana pendekatan struktural merupakan cara pengembangan SDM koperasi sebagai lembaga ekonomi dimana pelatihan harus benar-benar efektif. Pendekatan kultural lebih banyak menyoroti SDM koperasi dari sisi anggota dan masyarakat dan lingkungannya Kelurahan Beng Kecamatan Gianyar Kabupaten Gianyar. Perkembangan SDM didorong oleh kemajuan peradaban, pendidikan, ilmu pengetahuan, dan tuntunan daya saing produksi barang dan jasa. Peranan SDM diakui sangat menentukan bagi terwujudnya tujuan tetapi untuk memimpin unsur manusia ini sangat sulit dan rumit. Sumber daya manusia selain mampu, cakap, dan 
terampil juga tidak kalah pentingnya kemauan dan seungguhan mereka untuk belajra efektif dan efisien. Kemampuan dan kecakapan kurang berarti jika tidak diikuti moral kerja dan kedisiplinan karyawan dalam mewujudkan tujuan.

Adapun dalam Koperasi simpan pinjam Shanti Prapta Sedana,lingkungan kelod kangin Kelurahan Beng Kecamatan Gianyar Kabupaten Gianyar, SDM yang paling ingin dibina adalah anggota koperasi ini sendiri. Anggota koperasi, memiliki latar belakang anggota yang tidak sama, baik pendidikan, sosial ekonomi, agama maupun tanggung jawab keluarga. Dalam kasus koperasi anggota Koperasi lebih ,42orang maka Shanti Prapta Sedana,lingkungan kelod kangin Kelurahan Beng Kecamatan Gianyar Kabupaten Gianyar koperasi tersebut semakin besar sehinggga sulit untuk mengkoordinasi dan mengorganisasi anggota yang makin banyak itu. Karena semakin beraneka ragamnya tingkat kepentingan dan motivasi masingmasing anggota. Dengan latar belakang sosial ekonomi yang beraneka ragam ini jelas membawa persoalan yang tidak ringan bagi pemimpin organisasi koperasi, yang harus dapat membawa mereka ke satu tujuan bersama memotivasi mereka agar berpartisipasi secara optimal kepada koperasi.

Dari gambaran tersebut dapat disimpulkan bahwa sudah saatnya bagi koperasi mulai melihat dan meperlihatkan kualitas keanggotaan, bukan kuantitas atau jumlah anggota. Di sini prinsip keanggotaan koperasi yang sukarela mulai diterapkan dengan benar untuk memulai suatu koperasi yang baru, yang semuanya bertujuan menciptakan anggota koperasi yang bermotifasi tinggi. Mereka diharakan untuk lebih menyadari apabilah diarahkan dan lebih mudah diajak berpartisipasi aktif. Bagi anggota yang memperoleh informasi cukup sehingga memahami koperasi beserta kebijakan dan tindakannya diharapkan untuk lebih setia kepada koperasi, memiliki kepentingan yang lebih besar dengan koperasinya, lebih banyak mengajukan kritik dan saran yang membangun, bertindak sebagai salesman dalam koperasinya, memenuhi semua kewajiban dan melunasi segala pembayaran kepada koperasi. Bagi Koperasi Shanti Prapta Sedana yang memiliki anggota banyak, maka untuk mempemudah komunikasi dengan para anggota akan lebih efektif bila dibentuk kelompok-kelompok atau unit-unit aktivitas. Masing-masing kelompok dapat mengadakan pertemuan rutin sambil melatih dan membiasakan mereka saling belajar serta membantu kepentingan kelompoknya. Karena kekuatan koperasi berada di tangan anggotanya, maka kesadaran akan disiplin dan fanatisme anggota sangat penting guna meningkatkan pemahaman koperasi serta etos koperasi yang perlu ditanamkan pada setiap anggota (Suryaningsi \& Arif, 2020; Tabrani et al., 2019). Dengan demikian motivasi mereka dapat ditingkatkan secara bersama-sama dalam memenuhi kebutuhan dan keinginan ekonominya.

Koperasi Simpan Pinjam Santhi Prapta Sedana sendiri memiliki permasalahan yang cukup pelik pada keanggotannya. Anggota pada saat ini terdiri dari berbagai golongan masyarakat dengan tingkat perekonomian dan budaya masyarakat yang beragam. Pembinaan administrasi manajemen yang masih konvesional pada Koperasi Simpan Pinjam Santhi Prapta Sedana dilakukan dengan memberikan pendampingan, ceramah dan pembinaan kepada pengurus beserta anggota (Aryoko et al., 2016; Rufaidah, 2017; Wasiaturrahma et al., 2020; Zakiy et al., 2020). Pendampingan Koperasi Simpan Pinjam Santhi Prapta Sedana ini juga dilakukan via telefon, WhatsApp, Zoom Meeting, dan secara langsung agar lebih berjalan maksimal. Tim Pengabdian memberikan pendampingan dengan memberikan usulan-usulan terkait masalah penarikan kredit bermasalah dan membina para anggota yang bermasalah. Standar penanganan kredit bermasalah antara lain berkaitan dengan jangka waktu kredit sehingga keringanan yang diberikan adalah memperpanjang jangka waktu kredit, memperpanjang jarak waktu angsuran, missal semula angsuran ditetapkan setiap 3 bulan, kemudian menjadi 6 bulan, dan yang terakhir yaitu menurunkan jumlah untuk setipa angsuran yang mengakibatkan perpanjangan jangka waktu kredit. Reconditioning adalah bantuan yang diberikan adalah berupa keringanan atau perubahan persyaratan, penundaan pembayaran 
bunga, bunga yang terutang tersebut tidak dikenakan bunga dan tidak menambah plafon kredit, penurunan suku bunga, atau pembebasan bunga. Restructuring, yang dilakukan jika kesulitan usaha nasabah disebabkan oleh faktor modal, maka penyelamatannya adalah dengan meninjau kembali situasi dan kondisi permodalan, baik modal dalam arti dana untuk keperluan modal kerja maupun modal barupa barang-barang modal (mesin, peralatn, dan sebagainya). Pengambil alihan agunan, yang dilakukan apabila keadaan cashflow nasabah tidak mendukung untuk membayar kewajibannya, sementara nasabah masih memiliki itikad baik untuk menyelesaikan kewajibannya. Agunan tersebut sebaiknnya dijual untuk menutupi saldo pembiayaannya. Dan yang terakhir yaitu write off/ pemutihan/penghapusan kredit, dimana Write off adalah pinjaman macet yang tidak dapat ditagih lagi dan dihapus bukukan dari neraca (on-balance sheet) dan dicatat pada rekening administrative (off-balance sheet) (Kurniawan \& Kurniawan, 2018; Riyanto et al., 2021). Penghapus bukuan pinjaman macet tersebut dibebankan pada akun penyisihan penghapusan aktiva produktif.

\section{CONCLUSION}

Tim Pengabdian memberikan pendampingan dengan memberikan usulan-usulan terkait masalah penarikan kredit bermasalah dan membina para anggota yang bermasalah diantaranya reconditioning, restructuring, cashflow, write off.

\section{REFERENCES}

Aryoko, H., Tartini, T., \& Djafar, D. (2016). Pelatihan Dan Pendampingan Koperasi Serba Usaha (Simpan Pinjam, Pengelolaan Pasar Tradisional, Dan Mini Market) Writer: Eksis: Jurnal Riset Ekonomi Dan Bisnis, 11(2). https://doi.org/https://doi.org/10.26533/eksis.v11i2.44.

Christanto, F. W., Hendrawan, A., \& Pinem, A. P. R. (2019). Peningkatan Sumber Daya Manusia pada Koperasi FPM Jateng Sejahtera untuk Pengelolaan Sistem Informasi Manajemen. E-Dimas: Jurnal Pengabdian Kepada Masyarakat, 10(2), 137-143. https://doi.org/https://doi.org/10.26877/e-dimas.v10i2.3391.

Citra Savitri, \& Mumun Maemunah. (2021). Model Strategi Pemasaran Berbasis Digital Pada Koperasi Simpan Pinjam (Konsep Pada Koperasi Mugi Lestari). Jurnal Buana Pengabdian, $3(1)$,

107-114. https://doi.org/10.36805/jurnalbuanapengabdian.v3i1.1904.

Hadiwardoyo, W. (2020). Kerugian Ekonomi Nasional Akibat Pandemi Covid-19. Journal of Business \& Entrepreneurship Universitas Muhammadiyah Jakarta, 2(2), 83-92. https://doi.org/10.24853/baskara.2.2.83-92.

Kurniawan, D. A., \& Kurniawan, Y. I. (2018). Aplikasi Prediksi Kelayakan Calon Anggota Kredit Menggunakan Algoritma Naïve Bayes. Jurnal Teknologi Dan Manajemen Informatika, 4(1). https://doi.org/10.26905/jtmi.v4i1.1831.

Mariani, M., Shafira, N. H., \& Rahayu, W. S. (2021). Evaluasi Kinerja Koperasi Dalam Upaya Menigkatkan Kinerja Pengurus Pada Masa Pandemi Covid-19 (Studi Kasus Pada Koperasi Simpan Pinjam Cahaya Nararay, Desa Cimekar Kec. Cileunyi Kab.Bandung). Jurnal OPTIMA II, 5(1). https://doi.org/https://doi.org/10.33366/optima.v5i1.2709.

Purwantini, S., Rusdianti, E., \& Wardoyo, P. (2017). Kajian Pengelolaan Dana Koperasi Simpan Pinjam Konvensional Di Kota Semarang. Jurnal Dinamika Sosial Budaya, 18(1), 133. https://doi.org/10.26623/jdsb.v18i1.564.

Riyanto, E. A., Juninisvianty, T., Nasution, D. F., \& Risnandar, R. (2021). Analisis Kinerja Algoritma CART dan Naive Bayes Berbasis Particle Swarm Optimization (PSO) untuk Klasifikasi Kelayakan Kredit Koperasi. Jurnal Teknologi Informasi Dan Ilmu 
Komputer, 8(1), 55. https://doi.org/10.25126/jtiik.0812988.

Rufaidah, E. (2017). Pemberdayaan Perekonomian Masyarakat Melalui Koperasi Unit Desa Berbasis Usaha Terbimbing. AKADEMIKA: Jurnal Pemikiran Islam, 22(2), 361. https://doi.org/10.32332/akademika.v22i2.824.

Sujono, S., Mayasari, M. S., \& Koloniawan, K. (2019). Prototipe Aplikasi Simpan Pinjam Pada Koperasi Darma Karya Pangkalpinang Babel. Jurnal Sisfokom (Sistem Informasi Dan Komputer), 8(1), 68-73. https://doi.org/10.32736/sisfokom.v8i1.609.

Sumarni, Y. (2020). Pandemi COVID-19: Tantangan Ekonomi dan Bisnis. Jurnal Ekonomi Dan Perbankan Syariah IAIN Bengkulu, 6(2), 47-58.

Suryaningsi, S., \& Arif, F. M. (2020). Pengaruh Tingkat Pendidikan, Komitmen Organisasi dan Permodalan Terhadap Pertumbuhan Koperasi. Jurnal Riset Akuntansi Dan Keuangan, 8(2), 349-366. https://doi.org/10.17509/jrak.v8i2.21707.

Tabrani, M., Kholil, I., \& Sinnun, A. (2019). Implementasi Rapid Application Development Dalam Membangun Aplikasi Koperasi Simpan Pinjam (Studi Kasus Koperasi Subur $\begin{array}{lllll}\text { Jaya Mandiri Kabupaten Subang). Sistemasi, } & \text { 8(1), } & \end{array}$ https://doi.org/10.32520/stmsi.v8i1.439.

Wardana, L. K., \& Wulaningrum, P. D. (2020). Peningkatan Kinerja Kelompok Simpan Pinjam Melalui Pelatihan Administrasi Koperasi, Komunikasi Persuasive Dan Kewirausahaan. Ethos: Jurna; Penelitian Dan Pengabdian Masyarakat, 8(2), 154-161. https://doi.org/https://doi.org/10.29313/ethos.v8i2.5334.

Wasiaturrahma, W., Sulistyowati, C., Heriyati, D., \& Ajija, S. R. (2020). Peningkatan Kinerja Koperasi Melalui Pendampingan Manajemen Keuangan Pada Koperasi 64 Bahari Surabaya. Jurnal Berdaya Mandiri, 2(1), 256-267. https://doi.org/10.31316/jbm.v2i1.354.

Zakiy, M., Wardana, L. K., \& Vebrynda, R. (2020). Pendirian Koperasi Kelompok Usaha Bersama (Snack ) Dusun Kasihan Rt 6 Tamantirto Kabupaten Bantul D.I. Yogyakarta. Ethos: Jurnal Penelitian Dan Pengabdian Masyarakat, 8(2), 145-153. https://doi.org/https://doi.org/10.29313/ethos.v8i2.5333. 